near as great an advantage as an electric utility that owned the wires to its customers and thus controlled access to the market. Equally important, the means of production varies as much as the computing services produced. At one extreme, the peer-to-peer networks (famed for music and video sharing and now bringing massed computing power to problems such as protein folding and code breaking) require each consumer to be a producer too, which is the opposite of monopoly.

Frustratingly, Carr fails to ask whether or how technology itself might have altered the economics of electricity and industries like it. The telephone industry used to look a lot like the electricity industry, dominated by giant, regulated suppliers providing a commodity service. This situation is no more - and computing technology is largely to blame. Networked computers enable robust, distributed control of complex systems. Post-Internet, introducing a new service or a new competitor no longer requires an overhaul of the giant switches at the core of the network. Regulators permitting, innovators can just plug in and play.

Many in Silicon Valley, California, are now debating whether or not technology will do for the electricity grid what it has done for the telephone network. More and more households and companies are generating their own power, sometimes for ecological reasons, sometimes to take advantage of local sunshine, wind or water. Thanks to increasingly intelligent switching, many of these wind turbines, micro-hydro schemes and solar cells are linked back into the grid to compete with the giants of coal and nuclear power. This is also a potential revolution - running precisely opposite to the one Carr predicts.

The most puzzling, and disappointing, thing about Carr is that he remains a sceptic who makes little effort to question what he has read or been told. He just denounces it. Carr believes the conventional wisdom of both the computing and the electricity industries, but he wants everyone to know that the futures they predict won't be as much fun as they say they will. Patient analysis could have made a fascinating book. Yes, too much optimism can be blinding. But so can too much pessimism.

John Browning is a journalist based in London who has written extensively about technology, economics and the Internet.

\title{
FILM
}

\section{Water policy in the can}

\section{Emma Marris}

Many people regard access to safe drinking water as a human right. Yet some fear that the switch from state-run utilities to private ownership will lead to a world where water flows towards the rich as surely as it flows downhill, and where the poor, especially in the developing world, will be left thirsty.

Siding firmly against privatization of water resources, director Irena Salina's documentary FLOW: For Love of Water argues that profit-making is intrinsically incompatible with the United Nations Millennium Development Goal to "reduce by half the proportion of people without sustainable access to safe drinking water". Her film, which opens this week, uses case studies of privatization at its ugliest to excite moral outrage.

Some tales are developed more fully than others. Among the most effective is one that focuses on Ashok Gadgil, a researcher at Lawrence Berkeley National Laboratory in California, who as a child watched five cousins die from waterborne diseases. $\mathrm{He}$ was moved to invent a cheap device that uses ultraviolet light to disinfect water. The gadget now filters the water of half a million people in India. Similarly coherent is the segment on Michigan citizens battling a water-bottling plant run by the multinational food and beverage producer Nestlé that they feared was turning their creeks into drained mud flats.

Other stories are too big for one film. The section on current scandals and social

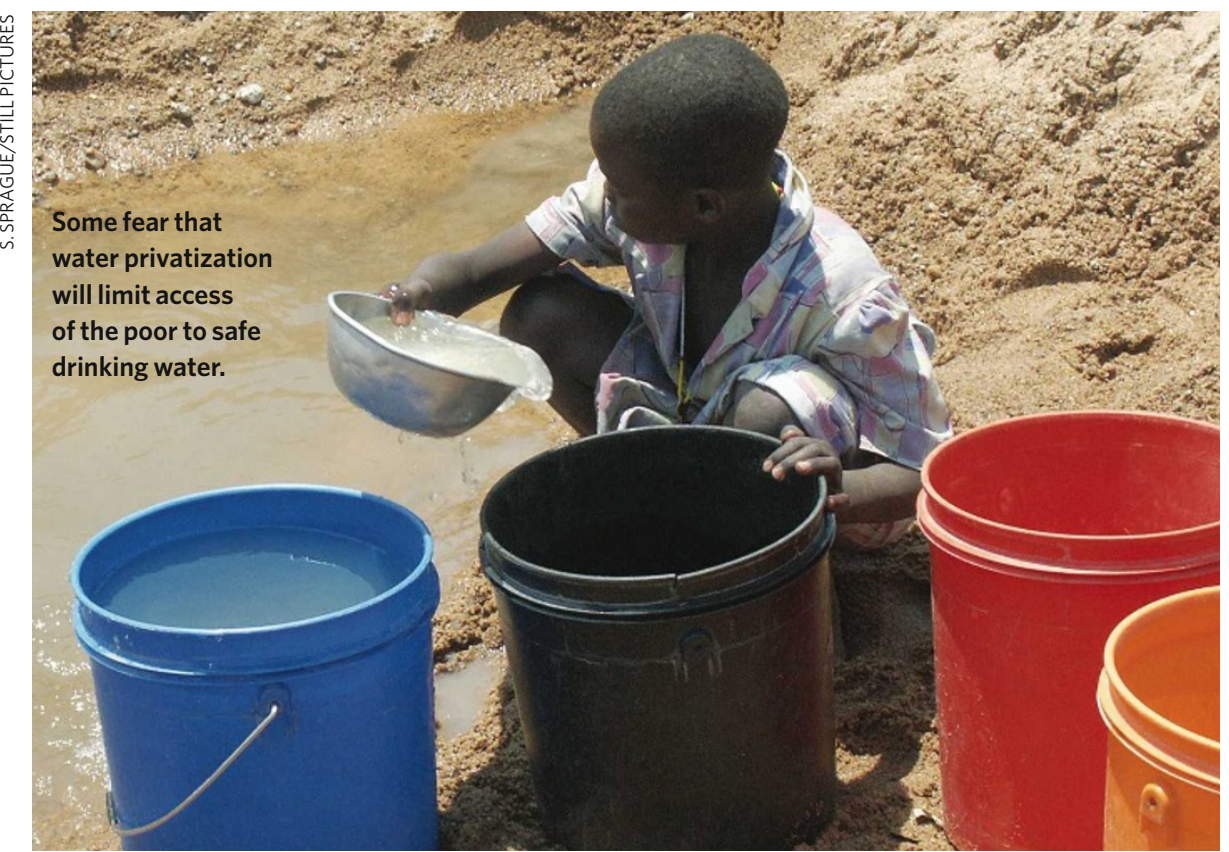

uprising against privatized water in Bolivia is confusing without more context and chronology. A look at the community effects of large dam projects seems hurried. An intriguing story of women plumbers in South Africa who secretly reactivate water supplies that have been shut off for non-payment gets short shrift.

One segment at first seems out of place among the tales of waterborne disease, future water wars and poor people deprived of water: the Western superstition that bottled water is safer and healthier than tap water. The revelation that it is not feels trivial until the film mentions an uncomfortable statistic. The United Nations estimates that the cost of providing safe, clean drinking water to the entire planet - US $\$ 30$ billion a year - is less than one-third the amount that the world spends on bottled water annually.

FLOW is intentionally one-sided. Salina presents no cases in which privatization improved the situation, despite there being a few published examples of local successes among many documented failures, such as fewer children dying in Argentine municipalities that privatized their water.

The movie does find time for a long, rousing climax and a call to action. The audience is asked to sign a petition to establish a new article in the Universal Declaration of Human Rights that reads: "Everyone has the right to clean and accessible water, adequate for the health and well-being of the individual and family, and no one shall be deprived of such access or quality of water due to individual economic circumstance."

FLOW zealously marshals a powerful set of arguments against water privatization. But a few more dry facts and a bit less fluid storytelling would have better served this important topic.

Emma Marris is a correspondent for Nature.

FLOW: For Love of Water is released on 21 March in Louisville, Kentucky, and across the United States later this year (www.flowthefilm.com). 